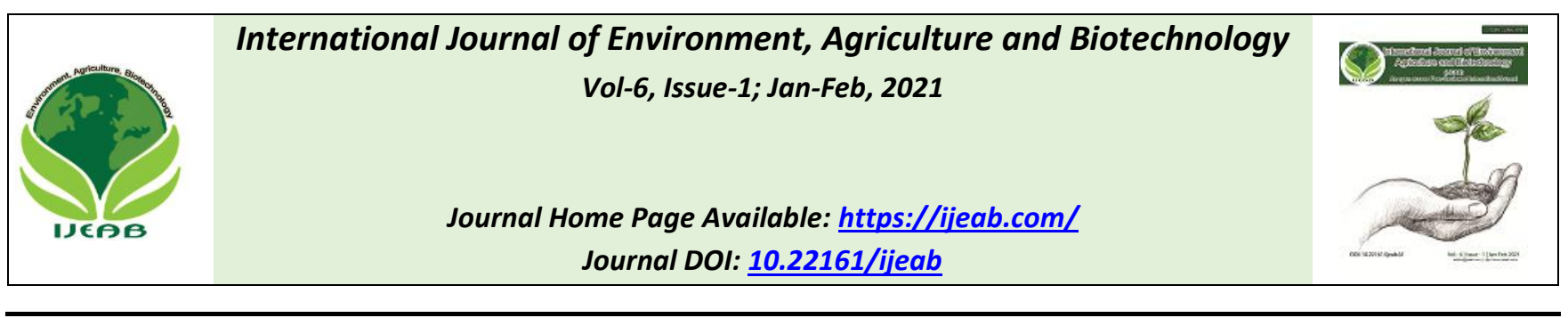

\title{
Phytochemical, Fluorescence and GC-MS Analysis of Methanolic Extract of Sterculia foetida L. Seeds
}

\author{
A. Amuthavalli ${ }^{1}$ and T. Ramesh ${ }^{2, *}$
}

\author{
${ }^{1}$ Mohamed Sathak College of Education, Kelambakkam, Chennai, India \\ ${ }^{2} \mathrm{PG} \&$ Research Department of Biotechnology, Hindustan College of Arts \& Science, Padur, Kelambakkam, Chennai, India \\ *Corresponding author
}

Received: 08 Nov 2020; Received in revised form: 04 Jan 2021; Accepted: 11 Jan 2021; Available online: 14 Jan 2021 (C)2021 The Author(s). Published by Infogain Publication. This is an open access article under the CC BY license (https://creativecommons.org/licenses/by/4.0/).

\begin{abstract}
The present work phytoconstituents of the seed powder of Sterculia foetidaL. extracted with $98 \%$ methanol. The extracted phytochemical compound subjected to qualitative analysis, quantitative analysis, fluorescence analysis and GC-MS analysis. The results of qualitative phytochemical screening confirm that the presence of tannins, phenols, steroids, cardiac glycoside and coumarin. The significant amount of carbohydrate, protein, lipid, tannin and total phenol estimated through quantitative analysis of phytochemicals. The seed powder with the picric acid exhibited fluorescent yellow during fluorescence analysis undertaken with short ultra violet light at $254 \mathrm{~nm}$. There are 13 bioactive compounds were identified through GC-MS analysis of seed powder of S. foetida L. These various bioactive compounds possess a wide range of activities such as disease control, pest control and microbicidal effect.
\end{abstract}

Keywords- Sterculia foetida, seed extracts, phytochemical screening, fluorescence analysis, GC-MS analysis.

\section{INTRODUCTION}

The medicinal plants are widely used in traditional medicine to prevent and treat various diseases. The phytoconstituents present in the various part of the plant can be exhibit anti-cancer, anti-tumour, anti-diabetic, antispasmodic, anti-inflammatory, anti-oxidant and antibacterial actvities ${ }^{23}$. Sterculia foetida is commonly called as Wild Indian almond belonging to the family Sterculiaceae. The fruits, seeds and leaves of $S$. foetida have been conventionally known for its many therapeutic purpose $^{5}$. A different variety of pharmacologically active compounds have been isolated from the leaves of $S$. foetida and these compounds from the leaves used as astringent, laxative, antifungal, anti-inflammatory and antiulcer medicines ${ }^{26}$. Nanadagopalan et al., $(2015)^{23}$ isolated twenty seven bioactive compounds from the methanolic extract of $S$. urens leaves. The important compounds present in the leaves extract were $3,7,11,15$-Tetramethyl2-hexadecen-1-ol, sucrose, 2, 4-Dihydroxy2, 5-dimethyl3(2H)-furan-3-one, 5(2H)-Oxazolone, 4-(phenylmethyl)-,
4H-Pyran-4-one, 2,3-dihydro-3,5-dihydroxy-6-methyl-, Megastigmatrienone and 2-Methoxy-4-vinylphenol etc and these compounds could contribute the medicinal quality of the $S$. foetida leaves. S. foetida seeds are not toxic and edible to humans and animals ${ }^{5}$. The bioactive compounds sterculinine-I, sterculinine-II, and soyacerebroside-I were isolated from the seeds of S. lychnophora ${ }^{34}$. In view of that the present work aimed to identify the pharmacologically active biomolecules responsible for anti-cancer and antioxidant from the methanolic extract of $S$. foetida seed.

\section{MATERIALS AND METHODS}

\subsection{Collection \& processing of plant sample}

Dried fruits of Sterculia foetida were collected from Kelambakkam-603103, Tamil Nadu, India. Seeds were identified and authenticated by Prof. P. Jayaraman, Director, Institute of Herbal Science, Plant Anatomy Research Centre (PARC), Chennai-600045. The seeds 
were collected from dried fruits were grinded and sieved to make fine powder for further study.

\subsection{Preparation of extracts}

Two fifty grams $(250 \mathrm{~g})$ from seed powder was extracted with $250 \mathrm{~mL}$ of $98 \%$ methanol in Soxhlet apparatus for 24 hours. After the extraction the crude extract was filtered through a Whatman number 1 filter paper. Later, the crude extract was subjected to evaporation in a rotary vacuum evaporator for dryness. After the evaporation process completed the concentrated extract was collected and stored at $4{ }^{\circ} \mathrm{C}$ for further analysis ${ }^{9,31}$.

\subsection{Qualitative analysis of phytochemicals}

Methanolic extract of $S$. foetida seed powder was subjected to qualitative phytochemical analysis. The phytochemical analysis such as Ferric chloride test and Lead acetate test for tannins ${ }^{28}$, Ferric chloride test and Gelatin test for phenols ${ }^{28}$, Libermann-Buchard test and Salkowski test for sterols ${ }^{28}$, Keller Killiani test for glycoside $^{28}$, Coumarin test for Coumarin ${ }^{27}$ and Phlobatanin test for Phlobatanin ${ }^{3}$ were performed.

\subsection{Quantitative analysis of phytochemicals}

The methanolic seed extract was subjected to quantitative analysis by spectrophotometer method. The extract was analyzed for Carbohydrate by Anthrone method ${ }^{12}$, Protein by Lowry's method ${ }^{20}$, Total Lipids ${ }^{35}$, Total Phenol ${ }^{2}$ and Total Tannin ${ }^{2}$.

\subsection{Fluorescence analysis}

Fluorescence analysis is the most important parameter of pharmacognostical evaluation. This analysis was carried out as per the standard protocol ${ }^{16,18,29}$. In the present work, the seed powder was treated with different solvents and chemicals. The seed powder was subjected to fluorescence analysis in visible/daylight and UV light (254 nm).

\subsection{GC-MS analysis}

Aim of this analysis is to identify the pharmacologically active biomolecule (anticancer \& antioxidant) present in the seed extract. The methanolic extract of $S$. foetida seed powder was subjected to GC-MS analysis on the instrument GC and MS JEOL GC mate equipped with secondary electron multiplier (Agilent Technologies $6890 \mathrm{~N}$ Network GC system for gas chromatography). The column (HP5) was fused silica $50 \mathrm{~m} \times 0.25 \mathrm{~mm}$ I.D. The study conditions were $20 \mathrm{~min}$. at $100^{\circ} \mathrm{C}, 235^{\circ} \mathrm{C}$ for column temperature at 3 minutes and $240^{\circ} \mathrm{C}$ for injector temperature, carrier gas was helium, and split ratio was $5: 4$. The $1 \mu \mathrm{l}$ of the sample was evaporated in a split-less injector at $300^{\circ} \mathrm{C}$ and the run time was $22 \mathrm{~min}$. The phytoconstituents of the extract was identified by Gas Chromatography coupled with Mass Spectrometry. The
GC-MS spectrum was analyzed using the NIST08 library which has more than 62,000 patterns $^{4,25}$.

\section{RESULTS AND DISCUSSION}

\subsection{Qualitative analysis of phytochemicals}

The essential information regarding the phytochemical constituents is generally determined through qualitative phytochemical analysis of plant extracts. The qualitative analysis of the methanolic seed extract showed the presence of secondary metabolites such as tannins, phenols, steroids, cardiac glycoside and coumarin and this analysis also confirmed that the absence of the phytochemical phlobatanin (Table 1). Tannin is an important secondary metabolite found in many plant species with remarkable amounts when compare to other secondary metabolites. Tannin can be present in various parts of plants such as roots, sap, stem, bark, leaves, fruits and seeds. Many researchers proved that the pharmacological properties of plant based secondary metabolites. Vieira Pereira et al., 2015 ${ }^{33}$ reported that tannin is a pharmacologically active metabolites and it act as astringent and insecticidal agent. Phenol and phenolic compounds contain antimicrobial property, hence they are used to treat skin infection and wound ${ }^{24}$. Phenol prevent the enzymes that cause antioxidant, inflammation, immune enhancers, hormone modulators and anti-clotting ${ }^{13}$. Sterols present in the plant possess anti-inflammatory effects and might enhance immune function ${ }^{7}$. Glycosides are considered as a useful drugs in therapeutics and it display antitumor activity and antiviral activity against rhinovirus $^{22}$. Researchers, Agarwal, 2000; Goodman \& Gilman's, 2006; Jain and Himanshu Joshi $2012^{1,8,15}$ proved that the anti-tumor, anti-cancer and anticoagulant activities of plant derived secondary metabolites coumarins. The above mentioned findings supported that the plant based secondary metabolites such as tannins, phenols, steroids, cardiac glycoside and coumarin have pharmacological properties.

Table 1: Phytochemicals present in the seed extracts of Sterculia foetida

\begin{tabular}{|c|c|c|}
\hline S. No. & Secondary metabolites & Results \\
\hline 1. & \multicolumn{2}{|l|}{ Tannins } \\
\hline & Ferric chloride test & + \\
\hline & Lead acetate test & + \\
\hline \multirow[t]{3}{*}{2.} & \multicolumn{2}{|l|}{ Phenols } \\
\hline & Ferric chloride test & + \\
\hline & Gelatin test & + \\
\hline
\end{tabular}




\begin{tabular}{|c|c|c|}
\hline \multirow[t]{2}{*}{3.} & \multicolumn{2}{|l|}{ Sterols } \\
\hline & Libermann-Buchard test & + \\
\hline & Salkowski test & + \\
\hline \multirow[t]{2}{*}{4.} & \multicolumn{2}{|l|}{ Glycoside } \\
\hline & Keller Killiani test & + \\
\hline \multirow[t]{2}{*}{5.} & \multicolumn{2}{|l|}{ Coumarin } \\
\hline & Coumarin test & + \\
\hline \multirow[t]{2}{*}{6.} & \multicolumn{2}{|l|}{ Phlobatanin } \\
\hline & Phlobatanin test & - \\
\hline
\end{tabular}

$+=$ Presence; - = Absence

\subsection{Quantitative analysis of phytochemicals}

The amount of Carbohydrate, Protein, Lipid, Phenol, and Tannin present in the seed extract was obtained by plotting the Optical Density value for the standard test tubes. The optical density value for sample tube is compared with one of the same optical density value of the standard tube. The optical density reading of the sample tube is plotted on the graph and the concentration of the component is determined. The amount of carbohydrate present in the
$2 \mathrm{ml}$ of seed sample is estimated to be $100 \mu \mathrm{g}$ as shown in the Fig. 1a. The amount of protein present in the $2 \mathrm{ml}$ of seed sample is estimated to be $20 \mu \mathrm{g}$ as shown in the Fig. 1b. The amount of lipid present in the $2 \mathrm{ml}$ of seed sample is estimated to be $50 \mu \mathrm{g}$ as shown in the Fig. 1c. The amount of phenol present in the $2 \mathrm{ml}$ of seed sample is estimated to be $60 \mu \mathrm{g}$ as shown in the Fig. 1d. The amount of tannin present in the $2 \mathrm{ml}$ of seed sample is estimated to be $60 \mu \mathrm{g}$ as shown in the Fig. 1e. The secondary metabolites like carbohydrate, protein and lipid have antioxidant, antimicrobial and antiviral properties ${ }^{21}$. According to the literatures, phenolic compounds are known to exhibit antioxidants, anticancer, antiinflammatory, antimicrobial, anti-allergic and antifertility activity ${ }^{14,30}$. Tannin is one among the major active secondary metabolite found in wide variety of plants ${ }^{11}$. Tannin has been reported to possessing antiviral, antioxidant, antibacterial and antitumor activity ${ }^{6,17}$. In the present work confirm that there is a significant quantities of pharmacologically active secondary metabolites such as carbohydrate, protein, lipid, phenol, and tannin are present.

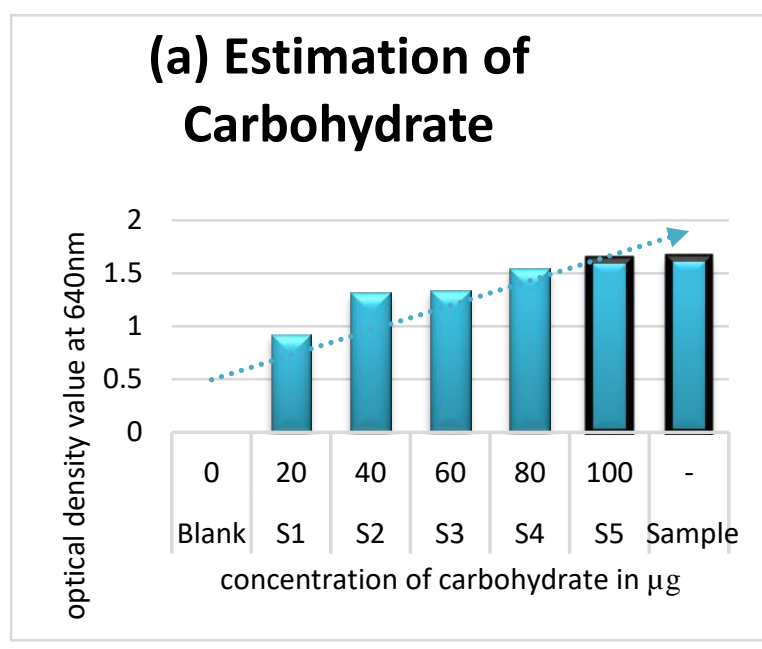

\section{(b) Estimation of Protein}
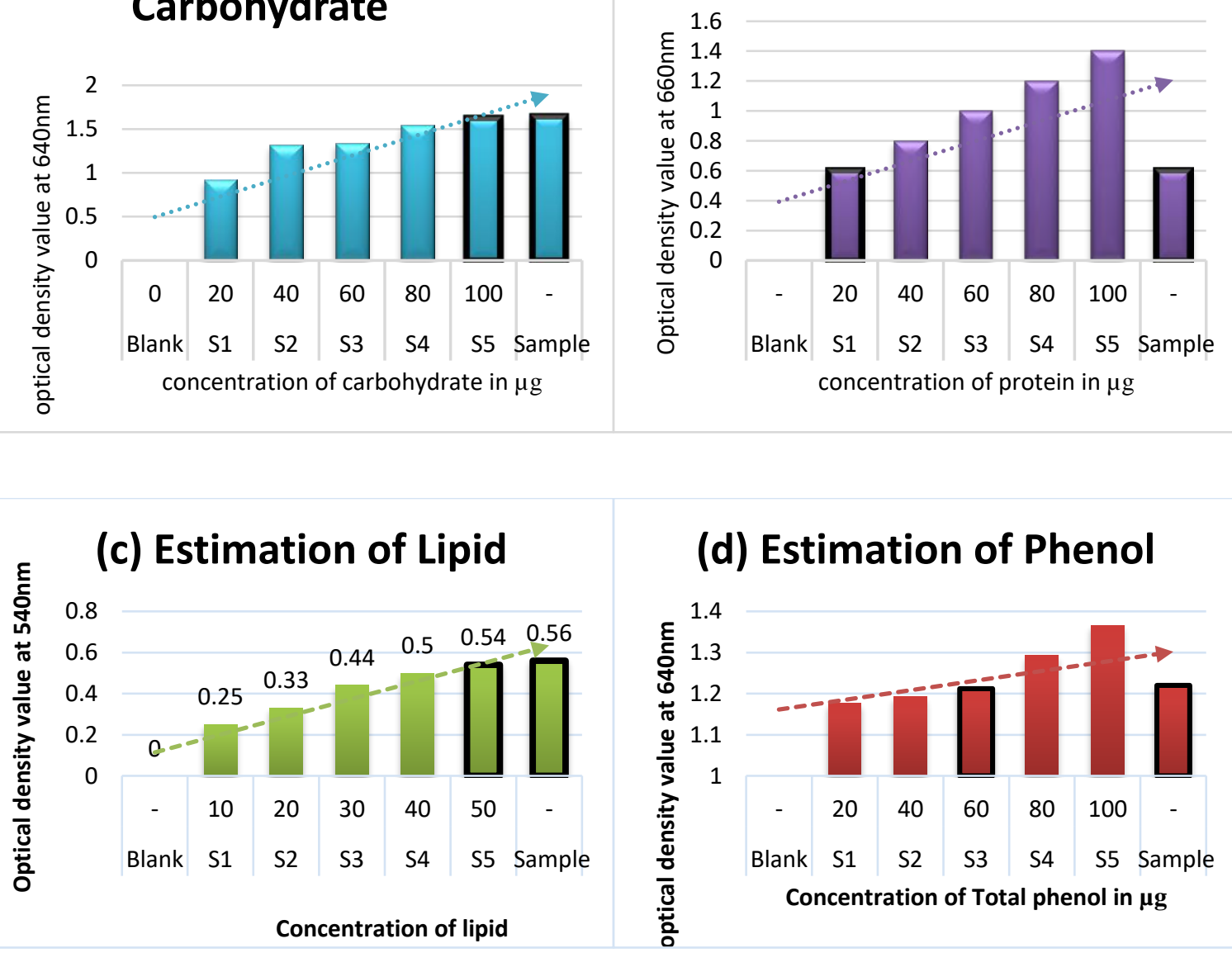

\section{(d) Estimation of Phenol}

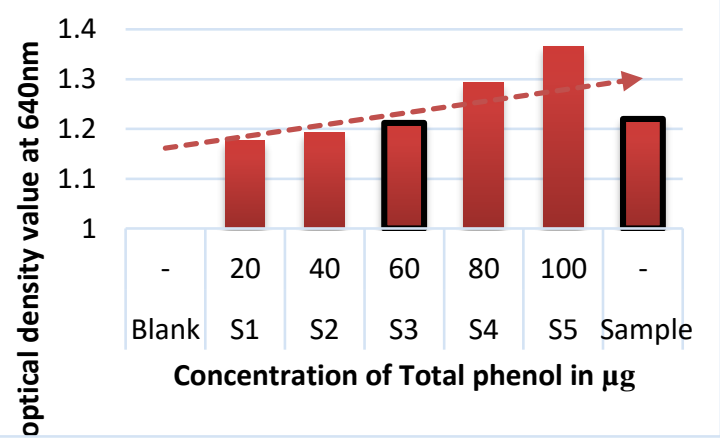




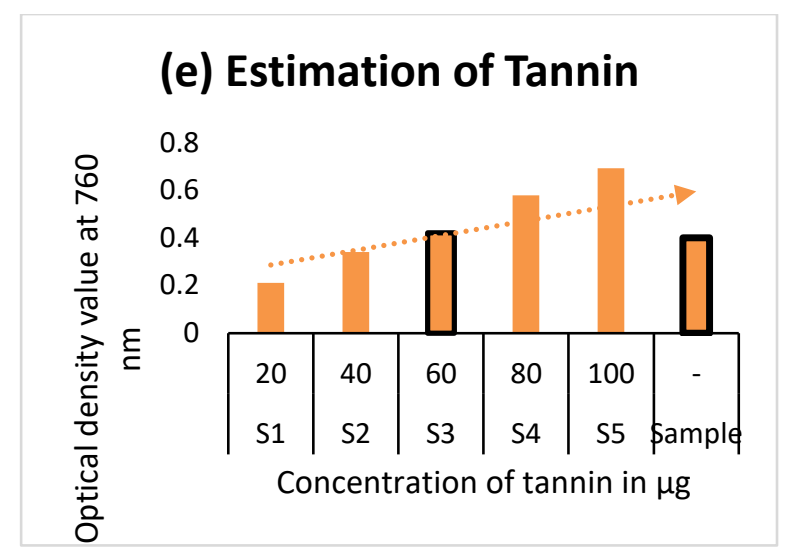

Fig 1 (a-e): The graphs showing results of quantitative analysis of methanolic extract of Sterculia foetida seed powder

\subsection{Fluorescence analysis}

The results of fluorescent analysis of dried seed powder of $S$. foetida with different chemical reagents are given in Table 2. The seed powder was treated with various solvents under visible and short UV light. Among the different solvents analyzed, picric acid showed characteristic coloration in both visible and UV light. Fluorescence analysis is a preliminary pharmacognostic parameter for determining various phytoconstituents present in the plant sample in short period of time ${ }^{19}$. The crude powder of plants shows different coloration when subjected to different chemical reagents at varied wavelength ${ }^{10}$. The researcher, VidyaKamble\& Nikhil Gaikwad (2019) ${ }^{32}$ reported that the secondary metabolites like coumarin, sapogenin and terpenoids show yellowish green fluorescence under short UV light. In the present work, the major bioactive metabolites present in the crude powder of $S$. foetida seed was found to be coumarin, phenols, tannins and sterols and this results could confirm that the pharmacognostic properties of $S$. foetida seed.

Table 2: Fluorescence analysis results of S. foetida seed powder

\begin{tabular}{|l|l|l|l|}
\hline S. No & \multicolumn{1}{|c|}{ Treatment } & \multicolumn{1}{c|}{ Visible light } & \multicolumn{1}{|c|}{ UV light (254 nm) } \\
\hline 1. & Powder & Light brown & Blackish brown \\
\hline 2. & Powder+Water & Light brown & Blackish brown \\
\hline 3. & Powder+NaoH & Reddish brown & Dark reddish brown \\
\hline 4. & Powder+HCl & Brown & Dark brown \\
\hline 5. & Powder+Acetic acid & Light brown & Dark brown \\
\hline 6. & Powder+Picric acid & Yellow & Yellowish green \\
\hline 7. & Powder+Sulphuric acid & Reddish brown & Dark Reddish brown \\
\hline 8. & Powder+Nitric acid & Brown & Dark brown \\
\hline 9. & Powder+Iodine & Brown & Dark brown \\
\hline 10. & Powder+Fecl 3 & Green & Dark green \\
\hline 12. & Powder+KOH & Brown & Dark brown \\
\hline 13. & Powder+Ammonia & Light brown & Dark brown \\
\hline 14. & Powder+Ethanol & Brown & Dark brown \\
\hline 15. & Powder+Alc.NaOH & Dark brown & \\
\hline
\end{tabular}




\subsection{GC-MS analysis}

The GC-MS analysis of methanolic extract of S. foetida seed powder divulge the presence of thirteen phytochemical compounds that could possess the pharmacological and microbicidal activity. The identification of the biomolecule was confirmed based on the retention time and molecular formula. The biologically active compounds with their Retention time (RT), Molecular formula, Molecular weight, Molecular structure and their Biological activity are presented in Table 3. The pharmacologically active major compounds present in the seeds were Flavanthrone \& Flavone (Anticancer activity), 5-Undecyne \& Methyl abietate (Antioxidant), 2cyclohexen-3-ol-1-one,2(11-phenylundecanoyl)

(Antidiuretic), Androstan-6-01-17-one,3-acetoxy-5A- chloro (Vasodilator) and Testosterone Cypionate (Antiinflammatory) apart from these compounds other major and minor compounds were also present. The GC-MS graph showing the compounds which showing anticancer (Figs. 2a \& b) and antioxidant (Figs. 2c \& d) activities are presented in Figs. 2 a-d. Similar to this study, twenty seven major phytochemical compounds were characterized through GC-MS analysis of the methanolic leaves extract of S. urens $\mathrm{Roxb}^{23}$. Asif Jafri et al., $2019^{5}$ reported that there were thirty five bioactive compounds were characterized via GC-MS analysis of the ethanolic extract of $S$. foetida seed and they were confirmed further that among 35 bioactive compounds many of them possess pharmacological activity and these findings are similar to the present work.

Table 3: Phytoconstituents identified in the seed sample of Sterculia foetida using GC-MS

\begin{tabular}{|c|c|c|c|c|c|c|}
\hline $\begin{array}{l}\text { S. } \\
\text { No }\end{array}$ & $\begin{array}{l}\text { Retention } \\
\text { time }\end{array}$ & Compound name & $\begin{array}{l}\text { Molecular } \\
\text { formula }\end{array}$ & $\begin{array}{l}\text { Molecular } \\
\text { weight }\end{array}$ & Structure & Activity \\
\hline 1 & 18.27 & Oleic acid & $\mathrm{C}_{18} \mathrm{H}_{34} \mathrm{O}_{2}$ & $282.468 \mathrm{~g} / \mathrm{mol}$ & & $\begin{array}{l}\text { Herbicide, } \\
\text { Insecticide \& } \\
\text { Fungicide }\end{array}$ \\
\hline 2 & 17.53 & $\begin{array}{l}\text { 10-Octadecenoic acid, } \\
\text { methyl ester }\end{array}$ & $\mathrm{C}_{18} \mathrm{H}_{34} \mathrm{O}_{2}$ & $282.468 \mathrm{~g} / \mathrm{mol}$ & & Insecticide \\
\hline 3 & 26.25 & Flavanthrone & $\mathrm{C}_{28} \mathrm{H}_{12} \mathrm{~N}_{2} \mathrm{O}_{2}$ & $408.416 \mathrm{~g} / \mathrm{mol}$ & & Anticancer \\
\hline 4 & 11.08 & 5-Undecyne & $\mathrm{C}_{11} \mathrm{H}_{20}$ & $152.281 \mathrm{~g} / \mathrm{mol}$ & & Antioxidant \\
\hline 5 & 16.05 & Flavone & $\mathrm{C}_{15} \mathrm{H}_{10} \mathrm{O}_{2}$ & $222.243 \mathrm{~g} / \mathrm{mol}$ & & Anticancer \\
\hline 6 & 16.6 & Palmitic acid & $\mathrm{C}_{16} \mathrm{H}_{32} \mathrm{O}_{2}$ & $256.43 \mathrm{~g} / \mathrm{mol}$ & & Herbicide \\
\hline 7 & 19.8 & Retinal,9-cis & $\mathrm{C}_{20} \mathrm{H}_{28} \mathrm{O}$ & $284.443 \mathrm{~g} / \mathrm{mol}$ & & $\begin{array}{l}\text { Cell } \\
\text { differentiation \& } \\
\text { Embryonic } \\
\text { development }\end{array}$ \\
\hline 8 & 20.75 & Methyl abietate & $\mathrm{C}_{21} \mathrm{H}_{32} \mathrm{O}_{2}$ & $316.485 \mathrm{~g} / \mathrm{mol}$ & & Antioxidant \\
\hline 9 & 21.5 & $\begin{array}{l}\text { Estra-1,3,5,(10)-trien- } \\
\text { 17a-ol,3-methoxy-17-(2 } \\
\text { methlallyl) }\end{array}$ & $\mathrm{C}_{18} \mathrm{H}_{22} \mathrm{O}$ & $254.373 \mathrm{~g} / \mathrm{mol}$ & & Antibacterial \\
\hline
\end{tabular}




\begin{tabular}{|c|c|c|c|c|c|c|}
\hline 10 & 22.15 & $\begin{array}{l}\text { 2-cyclohexen-3-ol-1- } \\
\text { one,2(11- } \\
\text { phenylundecanoyl) }\end{array}$ & $\mathrm{C}_{6} \mathrm{H}_{10} \mathrm{O}$ & $98.145 \mathrm{~g} / \mathrm{mol}$ & anmo & Antidiuretic \\
\hline 11 & 22.15 & $\begin{array}{l}\text { 3,9-Methano-10 } \mathrm{H}- \\
\text { furo[3,2-d] azonine- } \\
\text { 10,11-dione , 9- } \\
\text { [2]dimethyl amine]-3- } \\
\text { methoxyphenyl] } \\
\text { decahydro-2,6- } \\
\text { dimethyl-[2 } \\
\mathrm{R}^{\mathrm{X}}, 3 \mathrm{R}^{\mathrm{X}}, 3 \mathrm{a} 5^{\mathrm{X}}, 9 \mathrm{R}^{\mathrm{X}}, 10 \mathrm{AR} \\
\mathrm{x}_{\text {] }}\end{array}$ & $\mathrm{C}_{12} \mathrm{H}_{9} \mathrm{NO}$ & $183.21 \mathrm{~g} / \mathrm{mol}$ & & $\begin{array}{l}\text { Antibacterial \& } \\
\text { Antidote }\end{array}$ \\
\hline 12 & 22.73 & $\begin{array}{l}\text { Androstan-6-01-17- } \\
\text { one,3-acetoxy-5A- } \\
\text { chloro }\end{array}$ & $\mathrm{C}_{21} \mathrm{H}_{32} \mathrm{~N}_{2} \mathrm{O}$ & $328.5 \mathrm{~g} / \mathrm{mol}$ & S & $\begin{array}{l}\text { Vasodilator \& } \\
\text { Antimicrobial }\end{array}$ \\
\hline 13 & 23.78 & Testosterone Cypionate & $\mathrm{C}_{27} \mathrm{H}_{40} \mathrm{O}_{3}$ & $412.614 \mathrm{~g} / \mathrm{mol}$ & & $\begin{array}{l}\text { Anti- } \\
\text { inflammatory }\end{array}$ \\
\hline
\end{tabular}
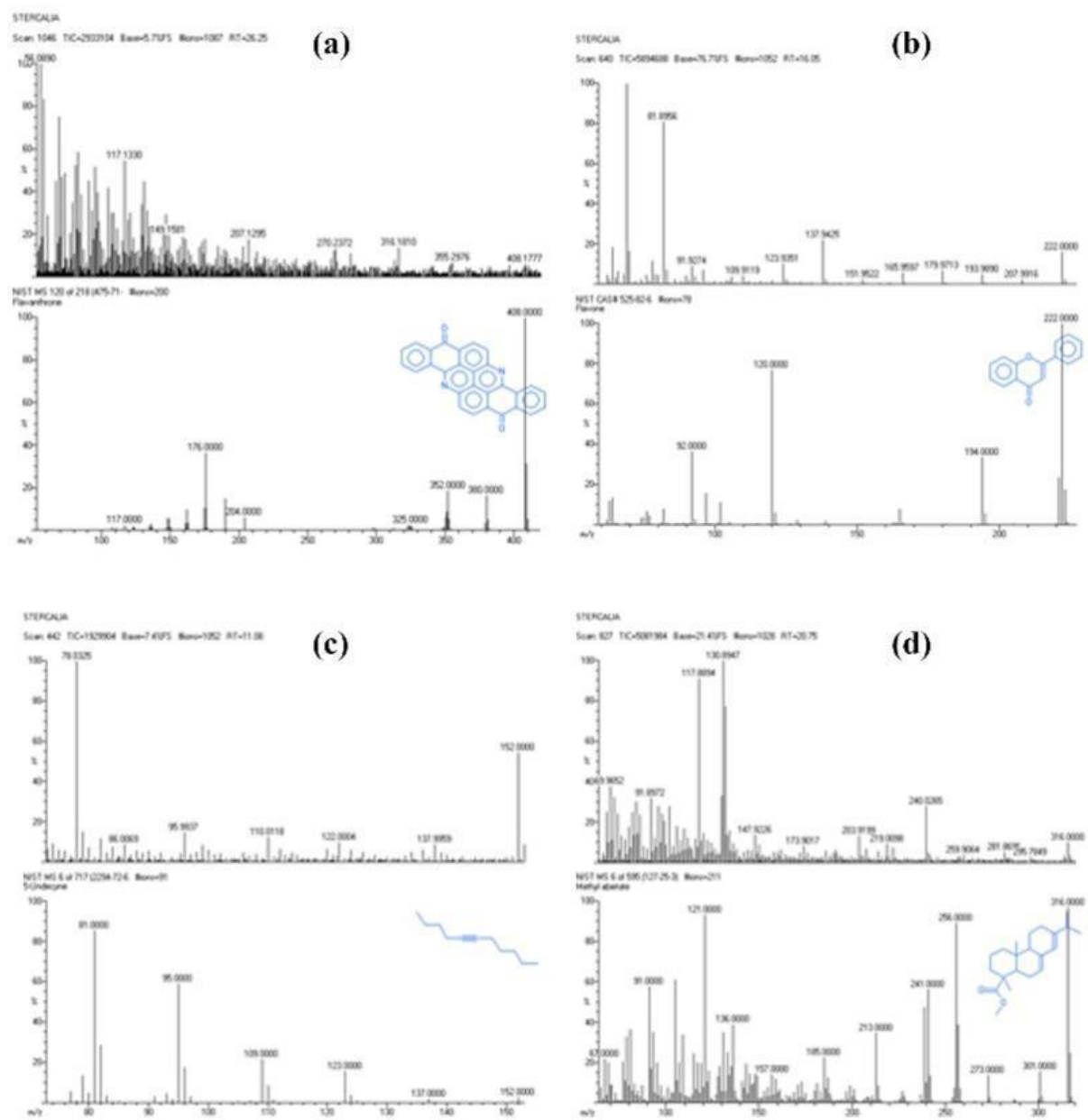

(a) Flavanthrone (b) Flavone (c) 5-Undecyne (d) Methyl abietate

Fig 2 (a-d): GC-MS graphs showing the compound possess anticancer and antioxidant activity 


\section{CONCLUSION}

On the basis of above findings, it can be concluded that the phytochemical screening and fluorescence analysis confirm that the methanolic extract of Sterculia foetida seed contains various pharmacologically active secondary metabolites. Furthermore, there are thirteen pharmacologically active biomolecules were identified through GC-MS study. Further studies are required to find out the efficacy of methanolic extract of Sterculia foetida seed as it may offer an effective alternative source against many diseases with less to no side effects.

\section{ACKNOWLEDGEMENT}

We would like to thank Sophisticated Analytical Instrument Facility (SAIF), Indian Institute of Technology Madras (IITM), Chennai-600 036, for GC-MS analysis.

\section{REFERENCES}

[1] Agarwal R., Synthesis \& biological screening of some novel coumarin derivatives, Biochem. Pharmacol.,6, 10421051 (2000)

[2] Ajiboye B.O., Ibukun E.O., Edobor G., Ojo A.O. and Onikanni, S.A., Qualitative and quantitative analysis of phytochemicals in Seneciobiafrae leaf, Inter. J. Inven. Pharma. Sci., 1(5), 428-432 (2013)

[3] Ajayi I.A., Ajibade O. and Oderinde R.A., Preliminary phytochemical analysis of some plant seeds, Res. J. Chem. Sci., 1(3), 58-62 (2011)

[4] Anand Duraiswamy, Devanand Shanmugasundaram and Changam Sheela Sasikumar, Evaluation of the phytochemical constituents in ADJ6, an anti-diabetic polyherbal formulation by GC-MS, J. Pharm. Phytochem., 5(1), 173-177 (2016)

[5] Asif Jafri, Shabana Banob, Juhi Raisa, Fahad Khanc, Neelam Shivnatha, Sharmab and Md Arshad, Phytochemical screening of Sterculia foetida seed extract for anti-oxidant, antimicrobial activity, and detection of apoptosis through reactive oxygen species (ROS) generation, mitochondrial membrane potential (MMP) decrease, and nuclear fragmentation in human osteosarcoma cells, J. Histotech., 42(2), 68-79 (2019)

[6] Falbe J. and Regitz M., CD ROMPP ChemieLexikon, Version 1.0, Georg Thieme, Stuttgart, Germany, (1995)

[7] Florence Brüll, Ronald P Mensink and Jogchum Plat, Plant sterols: functional lipids in immune function and inflammation? Clinic. Lipidology, 4(3), 355-365 (2009)

[8] Goodman and Gilman's, The Pharmacological basis of therapeutics: Blood coagulation and anti-coagulant, thrombolytic and anti-platelet drugs. 11th ed., 1325-1328 (2006)

[9] Gopalasathees kumar K., Significant role of soxhlet extraction process in phytochemical research, Mint $J$. Pharma. \&Medi. Sci., 7(1), 43-47 (2018)
[10] Gupta M.K., Sharma P.K., Ansari S.H., Lagarkha R., Pharmacognostical evaluation of Grewiaasiatica fruits, Int. J. Plant Sci., 1, 249-251 (2006)

[11] Haslam E., Natural polyphenols (vegetable tannins) as drugs: possible modes of action, J. Natur. Prod., 59(2), 205-215 (1996)

[12] Hedge J.E. and Hofreiter B.T., In: Methods in Carbohydrate Chemistry. Vol.17, (Eds.,) Whistler, R.L. and BeMiller, J.N., Academic Press, New York, p. 420 (1962)

[13] Iqbal Hussain, RiazUllah, RoohUllah, Muhammad Khurram, Naseem Ullah, Abdul Baseer, Farhat Ali Khan, Muneebur Rehman Khattak, Mohammad Zahoor, Jehangir Khan and Naeem khan, Phytochemical analysis of selected medicinal plants, Afri. J. Biotech., 10(38), 7487-7492 (2011)

[14] Jain A., Kateva S.S., Galav P.K. and Sharma P., Medicinal plant diversity of Sitamata wildlife santury, Rajasthan, India, J. Ethanopharmacol., 102, 143-157 (2005)

[15] Jain P. K. and Himanshu Joshi, Coumarin: Chemical and pharmacological profile, J. Appli. Pharma. Sci., 2(6), 236240 (2012)

[16] Kala S., Marimuthu Johnson, Narayanan Janakiraman, AntoArockiaraj A., Irudhaya Raj S., Bosco D., Pharmacognostic and phytochemical studies on some selected ethnomedicinal plants of Tamilnadu, South India, Int J Med Arom Plants1(2), 89-94 (2011)

[17] Khanbabaee K. and van Ree T., Tannins: classification and definition, Natur. Prod. Repo., 18(6), 641-649 (2001)

[18] Lala P.K., Lab Manuals of Pharmacognosy, CSI Publishers and Distributors, Calcutta, 5 th (Ed).,(1993)

[19] Lindley M., The impact of food processing on antioxidants in vegetable oils, fruits and vegetables, Trends Food Sci Technol., 9, 336-340 (1998)

[20] Lowry O.H., Rosebrough N.J., Farr A.L. and Randall R.J., Protein measurement with the Folin phenol reagent, J. Biol. Chem., 193, 265 (1951)

[21] Nagy Mahmoud Morsy, Phytochemical analysis of biologically active constituents of medicinal plants, Main Group Chem., 13(1), 7-21 (2014)

[22] Nagy Mahmoud Morsy, Cardiac glycosides in medicinal plants. In book: Aromatic and medicinal plants, Chapter 2 pp. 29-45 (2017)

[23] Nanadagopalan V., Johnson Gritto M. and Doss A., GCMS analysis of biomolecules on the leaves extract of Sterculia urensRoxb, J. Pharmaco and Phytochem., 3(6), 193-196 (2015)

[24] Okwu D.E., Evaluation of the chemical composition of indigenous spices and flavoring agents, Global J. Pure Appl. Sci., 8, 455-459 (2001)

[25] Radhakrishnan K., James F., Mohan A. and Chandra Mohan S., Gas chromatography and mass spectrometry analysis of Canthiumparviflorum leaves, Inno. J. Sci., 5(1), 22-27 (2017)

[26] Rani P.U. and Rajasekharreddy P., Insecticidal activity of (2n-octylcycloprop-1-enyl)-octanoic acid (I) against three coleopteran stored product insects from Sterculia foetida (L.), J Pest Sci., 83, 273-279 (2010) 
[27] Roghini R. and Vijayalakshmi K., Phytochemical screening, quantitative analysis of flavonoids and minerals in ethanolic extract of Citrus paradise, Int J Pharm Sci\& Res, 9(11), 4859-64 (2018)

[28] Saxena Mamta and Saxena Jyoti, Phytochemical screening of Acoruscalamus and Lantana camara, Inter. Res. J. Pharma, 3(5), 324-326 (2012)

[29] Shahabadkar G. Shamsundar and Swamy Paramjyothi, Preliminary pharmacognostical and phytochemical investigation on Sterculia foetida Linn. Seeds, Afri. J. Biotech., 9(13), 1987-1989 (2010)

[30] Soni V., Jha A.K., Dwivedi J. and Soni P. Qualitative and quantitative determination of phytoconstituents in some antifertility herbs, Indian J. Pharma. Sci., 80(1), 79-84 (2018)

[31] Terefe Tafese Bezuneh, Hinsermu Daba Derressa, Ramesh Duraisam and Alemu Mekonnen Tura, Preliminary evaluation of anti-termitic activity of Prosopisjuliflora leaf extract against Macrotermesspp (Isoptera: Termitidae), Cogent Environ. Sci., 5, 1-7 (2019)

[32] Vidya Kamble and Nikhil Gaikwad, Fluorescence analysis, phytochemical and antioxidant activities in leaves and stem of EmbeliaribesBurm. F., Asian J. Pharma and Clini Res., 12(4), 225-229 (2019)

[33] Vieira Pereira A., Mateus Santana G., Biondaro Góis M. and GonçalesSant'Ana D.M., Tannins obtained from medicinal plants extracts against pathogens: antimicrobial potential. In book: The Battle Against Microbial Pathogens: Basic Science, Technological Advances and Educational Programs, Chapter: 13, Publisher: Formatex Research Center, Editors: A. Méndez-Vilas, pp.228-235 (2015)

[34] Wang R.F., Wu X.W. and Geng D. Two cerebrosides isolated from the seeds of Sterculia lychnophora and their neuroprotective effect, Molecul.,18, 1181-1187 (2013)

[35] Zak B., Boyle A.J. and Zlatkis A., A method for the determination of cholesterol, J. Lab. Clin. Med., 41, 486492 (1953) 